\title{
Calpain-1 Catalytic Subunit
}

National Cancer Institute

\section{Source}

National Cancer Institute. Calpain-1 Catalytic Subunit. NCI Thesaurus. Code C123839.

Calpain-1 catalytic subunit (714 aa, $\sim 82 \mathrm{kDa}$ ) is encoded by the human CAPN1 gene. This protein is involved in proteolysis and the regulation of signal transduction and cytoskeletal modeling. 